\section{SIGHTINGS AND BEHAVIORAL OBSERVATIONS OF INDO-PACIFIC HUMPBACK DOLPHINS SOUSA CHINENSIS (OSBECK, 1765) ALONG ChENNAI COAST, BAY OF BENGAL}

\section{Rahul Muralidharan}

E4/253, $5^{\text {th }}$ Street, D.S. Nagar, Vandalur, Chennai, Tamil Nadu 600048, India rahulmuralidharan29@gmail.com

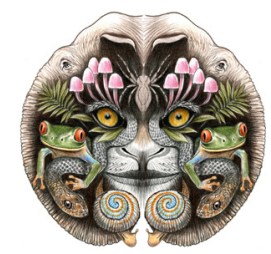

ISSN

Online 0974-7907 Print 0974-7893
Abstract: Boat-based surveys were used to investigate the presence of Indo-Pacific Humpback Dolphins Sousa chinensis along the coast of Chennai, Tamil Nadu, India. Notes were collected on behavior, group size, coloration patterns and group composition on sighting cetaceans during the surveys. Four groups of Indo-Pacific Humpback Dolphins were sighted near-shore in the month of February 2011, between 10-25 m depth with an average group size of 20 individuals of which 10 individuals were photo-identifiable. Dominant group behavior was aerial display, feeding and traveling. This study gives a basic idea of presence, threats and habitat use of Humpback Dolphin areas along Chennai coast.

Keywords: Bay of Bengal, behavior, Chennai coast, habitat use, photo identification, sightings, Sousa chinensis, Tursiops sp.

Indo-Pacific Humpback Dolphins Sousa chinensis have been recorded all along the Indian coast, from vesselbased and shore-based sightings, stranding records, incidental catch data, and museum specimens (Parsons 1998; Kumarran 2002; Parsons 2004; Sathasivam 2004; Sutaria \& Jefferson 2004; Afsal et al. 2008; Anoop et al. 2008; Reeves et al. 2008; Yousuf et al. 2008; Muralidharan 2011; Kumaran 2012; Vivekanandan \& Jeyabaskaran 2012). S. chinensis is placed under 'Near Threatened' (NT) category on the IUCN Red List (Reeves et al. 2008), but very few ecological studies on cetaceans have been carried out in India. Sutaria \& Jefferson (2004) studied the density and distribution of humpback dolphins along the Gujarat and Goa coasts of western India and provided records of strandings, sightings and incidental catches from India. The species has also been recorded from the coastal waters of Maharashtra (K. Jog \& M. Sule pers. comm. February 2012), from Kerala (Bijukumar et al. 2012; D. Panicker pers. comm. February 2012), from Karnataka (Sutaria pers. comm. February 2012) on the western coast, and Orissa (Sutaria 2009), Andhra Pradesh (Tripathy \& Choudhury 2004) and Tamil Nadu (S. Dharini pers. comm. February 2011) on the eastern coast. Being one of the four predominant delphinids and most recorded species in incidental catches in fishing gears in India (Afsal et al. 2008), research on humpback dolphins is urgently needed (Sutaria \& Jefferson 2004). In this study, we surveyed the Chennai coast for presence and behavior of $S$. chinensis, in relation to depth, distance from the shore and time of the day.

\section{Materials and Methods}

Study area: Chennai city is located in the state of

DOI: http://dx.doi.org/10.11609/JoTT.03454.5002-6 | ZooBank: urn:Isid:zoobank.org:pub:24BC1AD1-48DC-4469-A97D-BB6527D6DA52

Editor: Kumaran Sathasivam, Marine Mammal Conservation Network of India.

Date of publication: 26 November 2013 (online \& print)

Manuscript details: Ms \# 03454 | Received 23 December 2012 | Final received 20 October 2013 | Finally accepted 24 October 2013

Citation: Muralidharan, R. (2013). Sightings and behavioral observations of Indo-Pacific Humpback Dolphins Sousa chinensis (Osbeck, 1765) along Chennai coast, Bay of Bengal. Journal of Threatened Taxa 5(15): 5002-5006; http://dx.doi.org/10.11609/JoTT.03454.5002-6

Copyright: (c) Muralidharan 2013. Creative Commons Attribution 3.0 Unported License. JoTT allows unrestricted use of this article in any medium, reproduction and distribution by providing adequate credit to the authors and the source of publication.

Funding: TREE Foundation, Chennai, India.

Competing Interest: None.

Acknowledgements: I would like to thank TREE Foundation for funding this study and my supervisor Dr. Thirunavukkarasu for supporting me through the study period. I would also like to thank Mr. R.P. Kumarran and Mr. Nithyanandan Manickam for their encouragement and initial assistance. The surveys would not have been possible without the assistance of my friend Pugalarasu, who took me into the sea and brought me back safe to the shore. Thanks to Abdul Saeef for his excellent photos of dolphins during the survey, Sudharshan, Siddharth and Kaushik for assisting me with the software. I thank Dipani Sutaria for helping me write this note and the anonymous reviewers for their critical comments. 


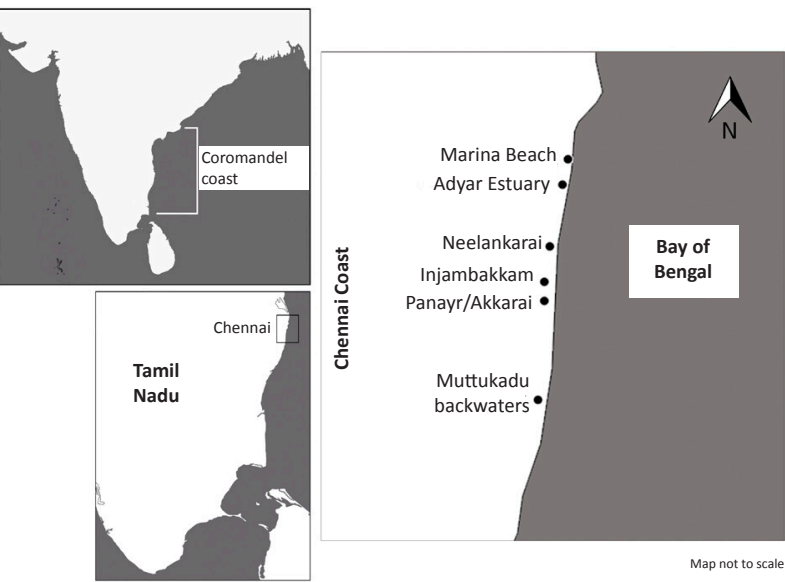

Image 1. Map of the study area

Tamil Nadu, which lies on the southeastern Coromandel Coast adjoining the Bay of Bengal (Image 1) of India. Approximately $300 \mathrm{~km}^{2}$ area between Adyar Estuary and Muttukadu Estuary was surveyed during this study (Image 1). The mouth to the estuaries where brackish water empties into the sea is considered the preferred habitat for S. chinensis (Jefferson \& Karczmarski 2001). The coast is surf beaten and interspersed with rocky reefs. The mean spring and neap tides are $1.21 \mathrm{~m}$ and $0.61 \mathrm{~m}$, respectively.

Field Methods: Surveys were carried out in the morning between 07:00 and 11:00 hr (Table 1). The survey tracks were perpendicular to the shore and were placed between Adyar Estuary in the north and Muttukadu backwaters to the south (Images $1 \& 2$ ). All the surveys originated from and ended at Neelangarai. Surveys were carried out using $10 \mathrm{~m}$ long FRP (FiberReinforced Plastic) boat with $12 \mathrm{hp}$ outboard engine. The average speed of the boat was maintained at $10 \mathrm{~km} /$ hr. Three observers, one at the bow and two on either
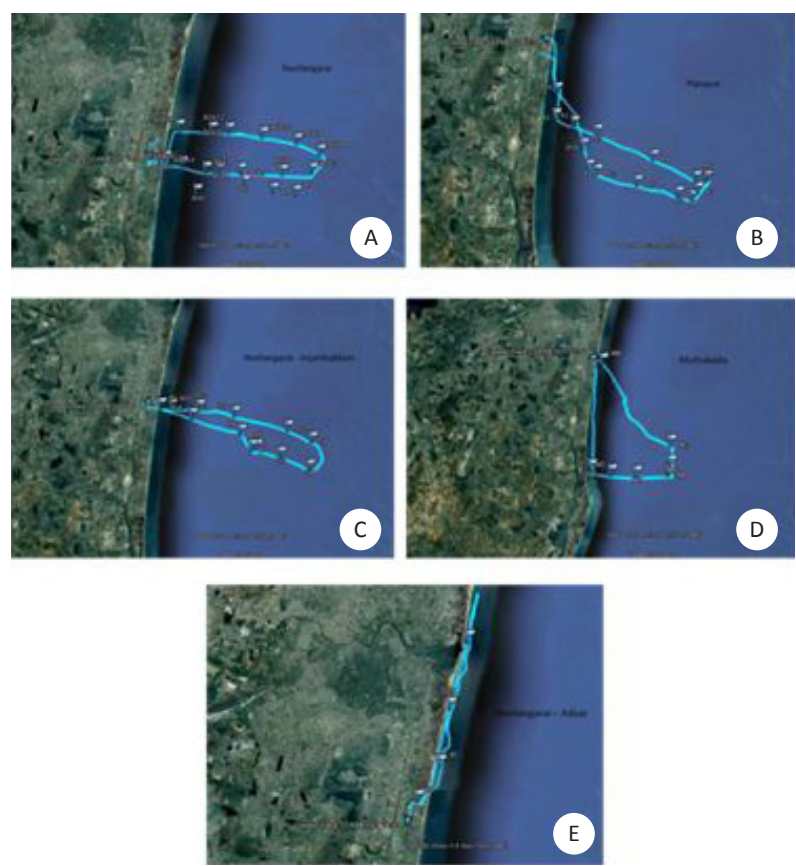

Image 2. Maps and dates of survey transects

A - Neelangarai 15 Feb 2011; B - Injambakkam 17 Feb 2011;

C - Panayur 18 Feb 2011; D - Injambakkam/Muttukadu 21 Feb 2011;

E - Neelangarai 22 Feb 2011

sides of the boat-searched for dolphins with naked eyes. When dolphins were sighted, the survey boat approached the group at a slower speed. Parameters such as depth, time, beaufort scale (BS), GPS coordinates, distance from shore, group size and associated species were noted. Bathymetry profile data for $25 \mathrm{~m}$ depth mark along Chennai coast were ascertained with GPS coordinates (Institute of Ocean Management, Anna University). We used Nikon D70 digital single-lens reflex camera 6.1 megapixel with 55-200 mm Nikkor lens and Canon Power Shot SX20 IS Digital Camera, with 12.1 Megapixels 20x Wide-Angle Zoom Lens (28-560 mm) to

Table 1. Sighting records of Indo-Pacific Humpback Dolphins along Chennai coast

\begin{tabular}{|c|c|c|c|c|c|c|c|}
\hline \multirow{2}{*}{$\begin{array}{c}\text { Sighting no./ } \\
\text { Time }\end{array}$} & \multirow{2}{*}{$\begin{array}{l}\text { Date of } \\
\text { sightings }\end{array}$} & \multirow{2}{*}{$\begin{array}{l}\text { Time of sighting } \\
\text { (hr) }\end{array}$} & \multirow{2}{*}{ Location } & \multirow{2}{*}{$\begin{array}{l}\text { Depth } \\
\text { (m) }\end{array}$} & \multirow{2}{*}{$\begin{array}{l}\text { Beaufort } \\
\text { scale }\end{array}$} & \multicolumn{2}{|c|}{$\begin{array}{c}\text { No. of dolphins } \\
\text { observed }\end{array}$} \\
\hline & & & & & & Min & Max \\
\hline 1 - 07:45-9:45 & 15 Feb 2011 & NS & Neelangarai & NA & 2 & - & - \\
\hline \multirow[t]{2}{*}{2 - 07:20-11:00 } & 17 Feb 2011 & 09:35-09:50 & Injambakkam & 20 & 2 & 6 & 10 \\
\hline & & 10:00-10:10 & Akkarai & 25 & 2 & 10 & 10 \\
\hline $3-08: 00-10: 30$ & 18 Feb 2011 & NS & Panayur & NA & 2 & NA & NA \\
\hline $4-08: 00-10: 30$ & 19 Feb 2011 & NS & Neelangarai & NA & 1 & NA & NA \\
\hline 5 - 07:00-12:00 & 21 Feb 2011 & 11:10-11:15 & Injambakkam & 20 & 2 & 20 & 30 \\
\hline $6-07: 00-11: 00$ & 22 Feb 2011 & 08:10-10:30 & Neelangarai & 10 & 2 & 10 & 35 \\
\hline
\end{tabular}

NA - not applicable; NS - no sightings 
photograph dorsal fins of individuals whenever possible.

\section{Results and Discussion}

The survey consisted of a total of 12 hours and $120 \mathrm{~km}$ of survey effort. The sea state was calm during early morning hours of the survey and changed gradually during the end of the survey period.

Four groups of humpback dolphins and two groups of Bottlenose Dolphins (Tursiops sp.) were sighted. All groups were sighted between 07:00am and 11:30am. Indo-pacific humpback dolphins were identified based on the coloration pattern and hump under the dorsal fin (Jefferson et al. 1993). Bottlenose dolphins were identified using body shape, triangular fin, shape and size of their snout, shape of rostrum, and relative length of the dolphin to the boat (Jefferson et al. 1993).

The observed bottlenose dolphins may be the IndoPacific Bottlenose Dolphin Tursiops aduncus, a distinct morphotype of Tursiops truncatus, which is an off-shore form. T. aduncus have been recorded before, during a near-shore research survey in the Bay of Bengal (Afsal et al. 2008) but further studies are required to ascertain the Tursiops species sighted in our surveys.

The estimated size of the S.chinensis groups ranged between 10-30 individuals with an average of 20 individuals in a group. A "group" here is defined as an aggregation of more than one dolphin, including all age classes or dolphin individuals within $20 \mathrm{~m}$ of each other, visible from the survey boat (Karczmarski 1999; Sutaria \& Jefferson 2004). S. chinensis are usually found in group sizes of 25 and less, but groups of less than 10 are most common (Jefferson \& Karczmarski 2001). All S.chinensis sightings were at depths less than $25 \mathrm{~m}$ with maximum and minimum depth recorded at $25 \mathrm{~m}$ and $10 \mathrm{~m}$, respectively (Table 1$)$. S. chinensis groups were sighted around 100-200 $\mathrm{m}$ from the shore, however, mixed groups of $S$. chinensis and Tursiops sp. were sighted nearly $5 \mathrm{~km}$ from the shore. S. chinensis have been frequently sighted in the study area in the years 2012 and 2013, after this study was completed.

Photographs with dorsal fins were analyzed based on picture quality (Excellent, Good, Medium). Of the totally usable photographs only $14 \%$ (good and excellent pictures) were used to identify individual fins. We photo-identified 10 individuals from 70 photographs (Images 3 \& 4). We used DARWIN software, Eckerd College, to produce a database for photo-identification based studies. We hope to build this database in the future to estimate population size and study movement patterns.

\section{Behavior observations}

On two occasions, mixed groups of $S$. chinensis and Tursiops sp. were encountered. On 17 February 2011, 09:35-09:50 hr, S. chinensis and Tursiops sp. were observed milling, i.e., swimming in a directionless fashion, but in the same location, off shore of Injambakkam. Again, the same mixed group was observed milling, diving randomly and circling in the same location, from 10:00-10:10 hr. Such milling behavior is seen during a foraging state in most cetaceans (Perrin et al. 2009). Short-term associations between humpback dolphins and bottlenose dolphins are known to occur elsewhere, in feeding areas that overlap or during foraging events (Karczmarski et al. 1997; Sayaman \& Tayler 1979). This

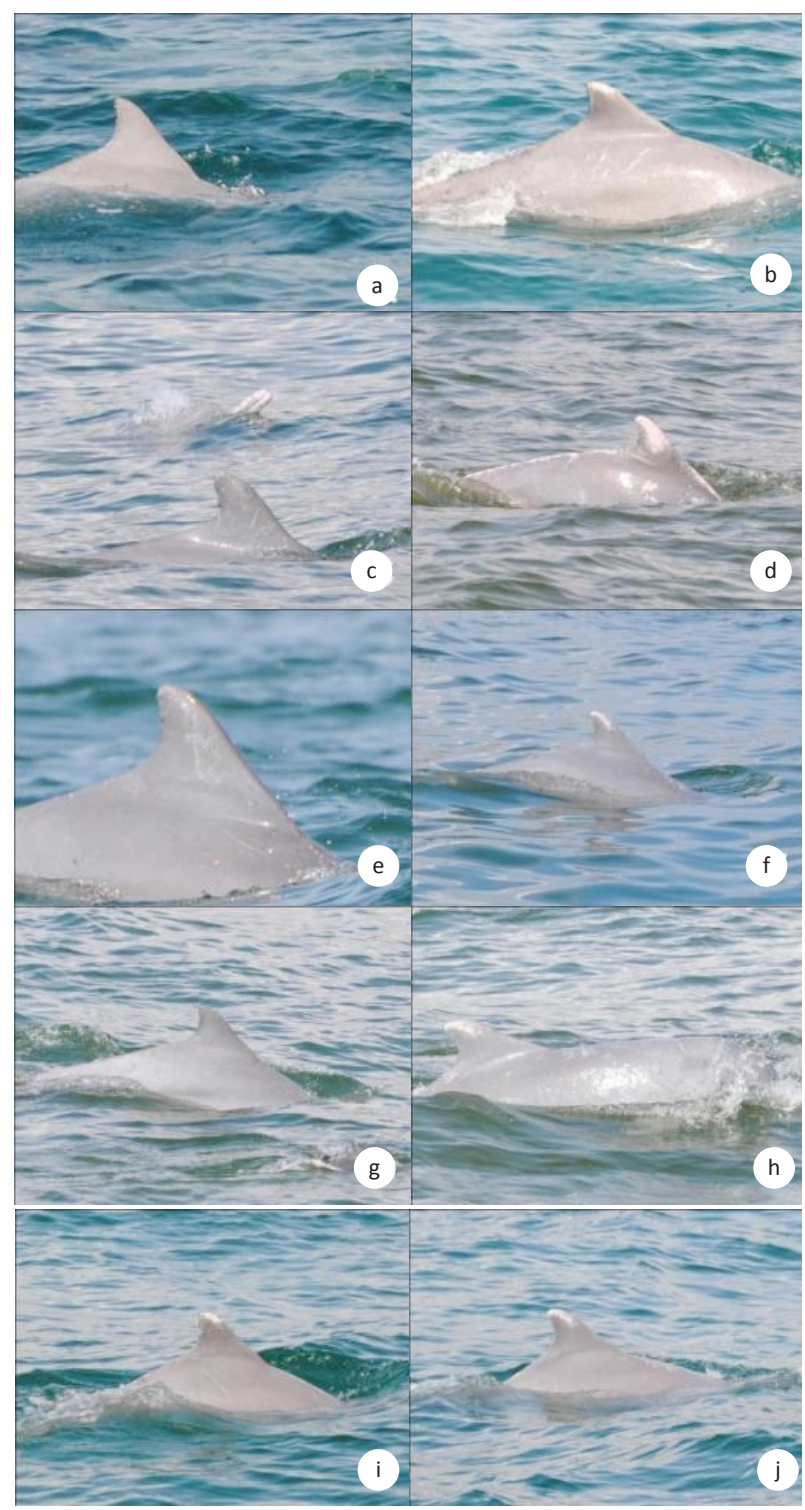

Image 3. (A to J) Humpback dolphins individual recorded during the study, Chennai coast, Bay of Bengal (February 2011). (C) Abdus Saeef 

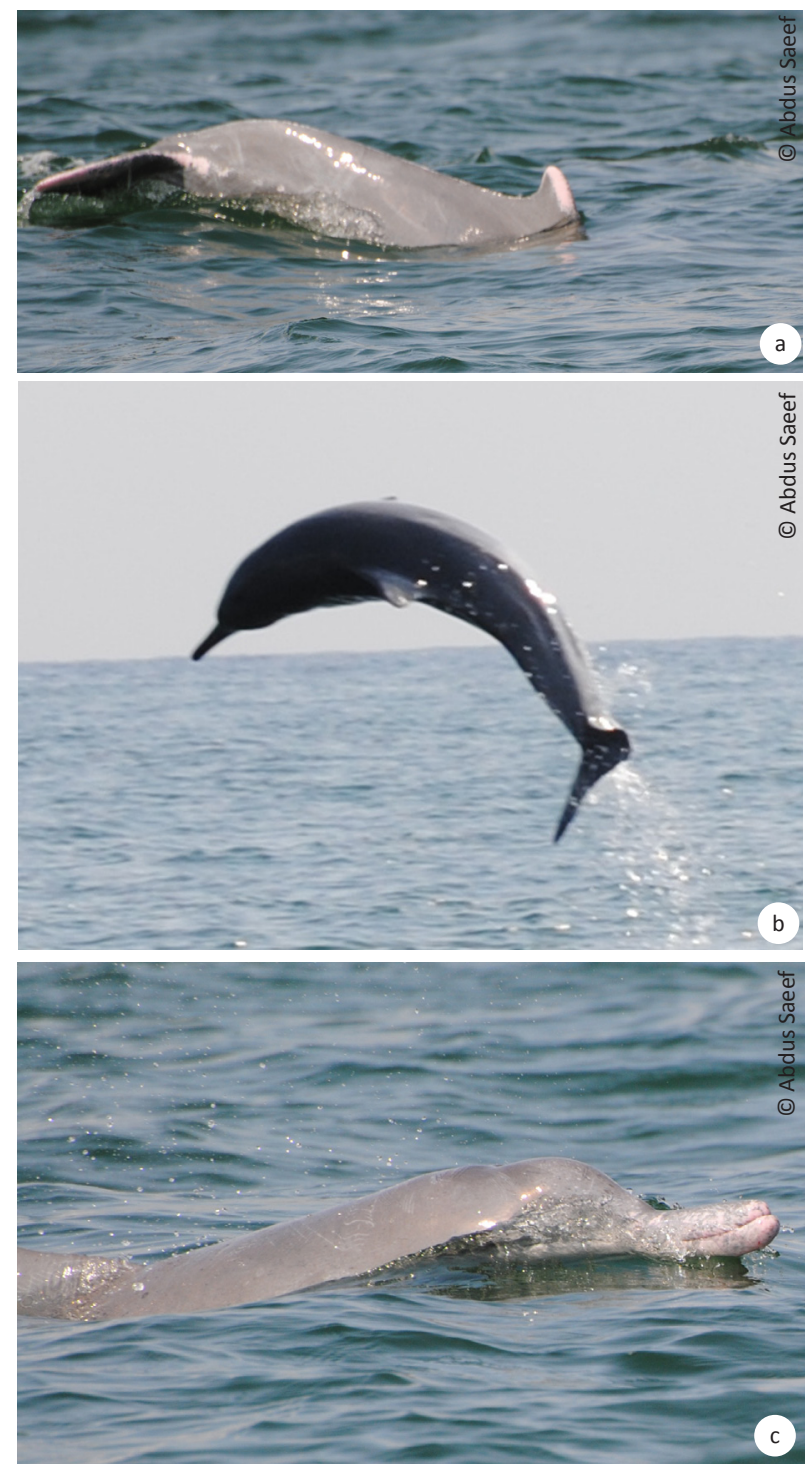

Image 4. Photographs of observed behaviors, Chennai coast (February 2011).

a - Tail slapping behavior; b - Humpback Dolphin breaching; c - Humpback dolphins' unique surfacing behavior, beak steeply emerges from water before forehead hits the surface

kind of behavioral association between the two species has also been well documented in South Africa and Australia (Jefferson \& Karczmarski 2001).

On 21 February 2011, at 11:10 hr, S. chinensis and Tursiops sp. were observed traveling perpendicular to the coast into deeper waters, near Injambakkam. However, the survey boat could not follow the group due to unfavorable sea conditions. We hypothesize that $S$. chinensis might swim farther offshore till the $20 \mathrm{~m}$ bathymetry line, or alternatively upriver due to tidal changes as these are predicted to have influence on distribution of S. chinensis (Parsons 1998; Sutaria \&
Jefferson 2004).

A group of humpback dolphins, ranging from 10-35 individuals, predominantly traveling with occasional aerial displays (Image 4), were followed from Neelangarai to Marina Beach covering a parallel shore distance of $7 \mathrm{~km}$ and a total of 02:20 hr, on 22 February 2011. Interestingly, two calves of $1 \mathrm{~m}$ length were noticed travelling with the adult dolphins. Calves are defined as animals two-thirds or less the length of an adult, regularly accompanying a larger animal, presumed to be the mother (Karczmarski 1999). Calves are usually more active in aerial displays and we hypothesize this large group, to be two 'mother-calf' groups meeting and socializing. Saayman \& Tayler (1979) interpreted aerial behavior as greeting displays when different groups of humpback dolphins meet.

S. chinensis and near-shore Tursiops sp. are susceptible to coastal gillnet fisheries (Jayasankaran et al. 2009). In our study area, both species have been reported as incidental catch by fishermen (S. Dharini pers. comm. February 2011). During this study, we observed the interactions between the dolphin groups and fisheries, in cases where both were present at a sighting. Most of $S$. chinensis sightings were observed in concurrence with shore seine fishing activity along the Chennai coast but direct feeding was not observed. It is probable that $S$. chinensis follow schools of fish to the shore, which the shore seiners also target. We also noticed that $S$. chinensis groups carefully avoided shore seine nets by swimming around them. Fishermen in the study area perceive that the presence of S. chinensis in their fishing grounds has reduced over the years. However, the exact reasons are unknown and studies are required to ascertain the conservation status of coastal cetaceans along the Chennai coast.

\section{Conclusion}

Due to the limited survey effort in our study area, we cannot ascertain if humpback dolphins are resident along the Chennai coast or are local migrants from close-by estuaries, but we hypothesize the latter based on scattered reports from fishers and from our observations. The Injambakkam area seems to be an important foraging habitat that overlaps for both $S$. chinensis and Tursiops sp. and is important for such mixed species groups. An increase in the number of records of $S$. chinensis off Chennai, in the months of Jan-Mar and May-Aug, suggests an overlap with an increase in near-shore prey. But, fishery interaction is recognized to be a primary threat to humpback dolphin population and needs to be assessed immediately to 
conserve the species (Mohan 1994; Kumarran 2002; Sutaria \& Jefferson 2004; Yousuf et al. 2008; Kumarran 2012). Long term seasonal observation and further investigation will yield critical information to understand the species and their range in detail, to mitigate threats.

\section{REFERENCES}

Afsal, V.V., K.S.S.M. Yousuf, B. Anoop, A.K. Anoop, P. Kannan, M Rajagopalan \& E. Vivekanandan (2008). A note on cetacean distribution in the Indian EEZ and contiguous seas during 2003-07. Journal of Cetacean Research and Management 10(3): 209-216.

Anoop, A.K., K.S. Yousuf, P.L. Kumaran, N. Harish, B. Anoop, V.V. Afsal, M. Rajagopalan, E. Vivekanandan, P.K. Krishnakumar and P. Jayasankar. (2008). Stomach contents of cetaceans incidentally caught along Mangalore and Chennai coasts of India. Estuarine, Coastal and Shelf Science 76(4): 909-913; http://dx.doi. org/10.1016/j.ecss.2007.08.004

Bijukumar, A. \& R. Smrithy (2012). Behaviour of Indo-Pacific Humpback Dolphin, Sousa chinensis (Osbeck) in the Ashtamud Estuary, southwest coast of India. Journal of Marine Biological Association of India 54(2): 5-10; http://dx.doi.org/10.6024/ jmbai.2012.54.2.01699-0x

Jayasankar, P., B. Anoop, M. Rajagopalan, K.S.S.M. Yousuf, P. Reynold, P.K. Krishnakumar, V.V. Afsal \& A.K. Anoop (2009). Indian Efforts on the inventorization of marine mammal species for their conservation and management. Asian Fisheries Science 22: 143-155.

Jefferson, T.A. \& L. Karczmarski (2001). Sousa chinensis. Mammalian Species 655: 1-9; http://dx.doi.org/10.1644/15451410(2001)655<0001:SC>2.0.CO;2

Jefferson, T.A., S. Leatherwood \& M.A. Webber (1993). FAO species Identification Guide. Marine Mammals of the World. FAO, Rome, 134-135pp.

Karczmarski, L. (1999). Group dynamics of Humpback Dolphins Sousa chinensisin the Algoa Bay region, South Africa Journal of Zoology (London) 249(3): 283-293; http://dx.doi. org/10.1111/j.1469-7998.1999.tb00765.x

Karczmarski, L., M. Thornton \& V. Cockroft (1997). Description of selected behaviours of Humpback Dolphins, Sousa chinensis. Aquatic Mammals 23: 127-134.

Karczmarski, L., P.E.D. Winter, V.G. Cockcroft \& A. McLachlan (1999). Population analyses of Indo-Pacific Humpback Dolphins Sousa chinensis in Algoa Bay, Eastern Cape, South Africa. Marine Mammal Science 15: 1115-1123.
Kumaran, P.L. (2002). Marine mammal research in India - a review and critique of the methods. Current Science 83(10): 1210-20.

Kumarran R.P. (2012). Cetaceans and cetacean research in India. Journal of Cetacean Research Manage 12(2): 159-172.

Mohan, R.S.L. (1994). Review of gillnet fisheries and cetacean bycatches in the northeastern Indian Ocean. Report International Whaling Commission (special issue) 15: 329-43.

Muralidharan, R. (2011). A Pilot Study on the Environmental Preference of Indo-Pacific Humpback Dolphins along the Chennai Coast, MSc Thesis. Madras Christian College, Madras University, Chennai, India.

Parsons, E.C.M. (1998). Observations of Indo-Pacific Humpback Dolphins, (Sousa chinensis), from Goa, Western India. Marine Mammal Science 14(1): 166-170.

Parsons, E.C.M. (2004). The Behavior and Ecology of the Indo-Pacific Humpback Dolphin (Sousa chinensis). Aquatic Mammals 30(1): 38-55.

Reeves, R.R., M.L. Dalebout, T.A. Jefferson, L. Karczmarski, K. Laidre, G. O'Corry-Crowe, L. Rojas-Bracho, E.R. Secchi, E. Slooten, B.D. Smith, J.Y. Wang \& K. Zhou (2008). Sousa chinensis. In: IUCN 2012. IUCN Red List of Threatened Species. Version 2012.2. <www. iucnredlist.org>. Downloaded on 17 February 2013.

Saayman, G.S. \& C.K. Tayler (1979) The socioecology of Humpback Dolphins (Sousa sp.), pp. 165-226. In: Winn, H.E. \& B.L. Olla (eds.). Behavior of Marine Animals; Cetaceans - 3. Plenum Press, New York, 438pp.

Sathasivam, K. (2004). Marine Mammals of India. Universities Press (India), Private Limited, Hyderguda, India, 180pp.

Sutaria, D. (2009). Species conservation in a complex socio-ecological system: Irrawaddy Dolphins, Orcaella brevirostris in Chilika Lagoon, India (Doctoral dissertation, James Cook University)

Sutaria, D. \& T.A. Jefferson (2004). Records of Indo-Pacific Humpback Dolphins (Sousa chinensis, Osbeck, 1765) along the coasts of India and Sri Lanka : an overview. Aquatic Mammals (Special Issue) 30: 125-136.

Tripathy, B. \& B.C. Choudhury (2004). Occurrence and mortality of marine mammals along the Andhra Pradesh coast, east coast of India. Indian Forester 130(10): 1132-1140.

Vivekanandan, E. \& R. Jeyabaskaran (2012). Marine Mammal Species of India. Central Marine Fisheries Research Institute, Kochi, India,228pp+146pls.

Yousuf, K.S.S.M., A.K. Anoop, B. Anoop, V.V. Afsal, E. Vivekanandan, R.P. Kumarran, M. Rajagopalan, P.K. Krishnakumar \& P. Jayasankar (2008). Observations on incidental catch of cetaceans in three landing centres along the Indian coast. Journal of Marine Biological Association (JMBA) Biodiversity Records 2: 1-6. 